\title{
Mycoplasma pneumoniae induces airway epithelial cell expression of MUC5AC
} in asthma

\author{
M. Kraft*, K.B. Adler, J.L. Ingram*, A.L. Crews" ${ }^{\#}$ T.P. Atkinson ${ }^{\star}$, C.B. Cairns*, \\ D.C. Krause ${ }^{+}$and H.W. Chu ${ }^{\S}$
}

ABSTRACT: As excess mucin expression can contribute to the exacerbation of asthma, the present authors hypothesised that Mycoplasma pneumoniae significantly induces MUC5AC (the major airway mucin) expression in airway epithelial cells isolated directly from asthmatic subjects.

A total of 11 subjects with asthma and six normal controls underwent bronchoscopy with airway brushing. Epithelial cells were cultured at an air-liquid interface and incubated with and without M. pneumoniae for $48 \mathrm{~h}$, and in the presence and absence of nuclear factor (NF)- $\mathrm{kB}$ and a toll-like receptor (TLR)2 inhibitor. Quantitative PCR was performed for MUC5AC and TLR2 mRNA. MUC5AC protein and total protein were determined by ELISA.

M. pneumoniae exposure significantly increased MUC5AC mRNA and protein expression after $48 \mathrm{~h}$ in epithelial cells isolated from asthmatic, but not from normal control subjects, at all concentrations as compared to unexposed cells. TLR2 mRNA expression was significantly increased in asthmatic epithelial cells at $4 \mathrm{~h}$ compared with unexposed cells. NF- $\mathrm{B}$ and TLR2 inhibition reduced MUC5AC expression to the level of the unexposed control in both groups.

Mycoplasma pneumoniae exposure significantly increased MUC5AC mRNA and protein expression preferentially in airway epithelial cells isolated from asthmatic subjects. The toll-like receptor 2 pathway may be involved in this process.

\section{KEYWORDS: Asthma, epithelial cell, MUC5AC, Mycoplasma pneumoniae, toll-like receptor 2}

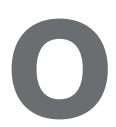
bstructive airway diseases, such as asthma and chronic obstructive pulmonary disease, are characterised by goblet cell hyperplasia and enhanced mucus secretion [1]. Specific pathogens, including Haemophilus influenzae, Staphylococcus pneumoniae, Pseudomonas aeruginosa, Mycoplasma pneumoniae, rhinovirus and respiratory syncytial virus, have been shown to increase mucus secretion [2-6]. Therefore, excessive mucus secretion may be a mechanism of infection-induced exacerbation of airway disease.

The major mucin protein in the asthmatic airway is MUC5AC, where expression is $60 \%$ higher in asthmatics as compared with normal control subjects [1]. CHU et al. [4] demonstrated a significant increase in MUC5AC expression after ovalbumin (OVA) sensitisation and challenge in BALB/c mice, which further increased when mice were infected with $M$. pneumoniae after OVA. However, this finding has not been directly demonstrated in human asthma.

M. pneumoniae is a known cause of asthma exacerbations [7-9] and binds to toll-like receptor
(TLR)2 on airway epithelial cells to initiate an inflammatory response [4]. The present authors hypothesised that $M$. pneumoniae increases airway MUC5AC expression preferentially in asthma as compared with normal controls.

\section{MATERIALS AND METHODS \\ Study subjects}

At total of 17 subjects were recruited from the general Denver (CO, USA) and Durham (NC, USA) communities. The asthmatics fulfilled criteria for asthma [10], exhibiting a provocative concentration of methacholine resulting in a $20 \%$ fall in forced expiratory volume in one second (FEV1) of $<8 \mathrm{mg} \cdot \mathrm{mL}^{-1}$ and reversibility of spirometry of $\geqslant 12 \%$ with inhaled albuterol. Only subjects on as-needed short-acting $\beta_{2}$-agonists alone were recruited; no medications were discontinued. Exclusion criteria included: postbronchodilator FEV1 <50\% predicted; in-patient status; respiratory tract infection within 3 months of study; use of any controller therapy within 4 weeks of study; smoking history $>5$ pack-yrs or any cigarette use within the previous 2 yrs;

\section{AFFILIATIONS}

*Dept of Medicine and Surgery, Duke University Medical Center, Durham, \#Dept of Molecular Biomedical Sciences, North Carolina State University, Raleigh, NC,

"Dept of Pediatrics, University of Alabama, Birmingham, AL, ${ }^{\text {s}}$ Dept of Medicine, National Jewish Medical and Research Center, Denver, CO, and

+Dept of Microbiology, University of Georgia, Athens, GA, USA.

\section{CORRESPONDENCE}

M. Kraft

Duke University Medical Center

MSRB M275

Research Drive

Durham

NC 27710

USA

Fax: 19196848408

E-mail: monika.kraft@duke.edu

Received:

August 092007

Accepted after revision:

September 212007

SUPPORT STATEMENT

This study was supported by National Heart, Lung and Blood Institute grant numbers HL P01-HL073907 and R37 HL36982.

\section{STATEMENT OF INTEREST}

Statements of interest for M. Kraft and K.B. Adler can be found at www.erj.ersjournals.co.uk/misc/ statements.shtml

European Respiratory Journal Print ISSN 0903-1936 Online ISSN 1399-3003 
significant nonasthma pulmonary disease or other medical problems. All subjects provided consent to participate in this institutional review board-approved protocol.

\section{Bronchoscopy}

Subjects underwent bronchoscopy with endobronchial protected brushing to airway epithelial cells for culture, as previously described [11]. Supplemental oxygen was administered throughout the procedure along with monitoring of heart rate, blood pressure and oxygen saturation.

\section{Airway epithelial cell culture and exposure to M. pneumoniae}

Primary epithelial cells were cultured at an air-liquid interface in an identical fashion for asthmatic and normal subjects, as previously described [12]. Immunostaining using an antihuman pan cytokeratin antibody (Sigma, St. Louis, MO, USA) confirmed epithelial cell origin. Stock concentration of $M$. pneumoniae (ATCC 15331) was prepared as previously described [12] and was diluted with bronchial epithelial cell culture media to obtain designated concentrations of 10, 20 and 50 colony-forming units $(\mathrm{cfu}) \cdot \mathrm{cell}^{-1}$, respectively. M. pneumoniae was added to the apical surface in the exposed conditions and incubated for $4 \mathrm{~h}$ to determine TLR2 mRNA expression, and for $48 \mathrm{~h}$ for MUC5AC mRNA and protein determination. These time-points were chosen because CHU et al. [4] demonstrated maximal nuclear factor (NF)- $\mathrm{\kappa B}$ activation at $4 \mathrm{~h}$ in cell lysates of lung extracts from BALB/c mice infected with M. pneumoniae, and maximal MUC5AC mRNA and protein expression at 48-72 h. An NF-кB inhibitor, cafeic acid phenylethyl ester (Sigma, $10 \mu \mathrm{M}$ ) and a TLR2 inhibitor (HM2064; Hycult Biotechnology, Uden, the Netherlands), the latter at $50{\mathrm{cfu} \cdot \mathrm{cell}^{-1}}^{-1}$ only, were added to a subset of cells separately, each at $10 \mu \mathrm{M}$ $30 \mathrm{~min}$ before exposure to M. pneumoniae [13]. As an additional control, cells were exposed to a mutant M. pneumoniae (organism II-3) that contains a mutation at the P1 adhesion structure on the organism, and is therefore unable to adhere effectively to airway epithelial cells [14].

\section{Airway epithelial cell MUC5AC and TLR2 mRNA expression and MUC5AC protein expression}

Airway epithelial mRNA expression levels for MUC5AC and TLR2 were determined using reverse transcription, followed by real-time quantitative PCR, as previously reported [4]. The threshold cycle $(\mathrm{Ct})$ was recorded for each sample and the comparative $\mathrm{Ct}$ method was used to represent the relative gene expression levels [15].

MUC5AC protein was determined in cell supernatants by direct ELISA, utilising the MUC5AC-specific 45M1 antibody, as previously described [16]. Total protein was determined using Bradford assay (Bio-Rad Laboratories, Hercules, CA, USA). The detection range for the MUC5AC ELISA was 5$60 \mathrm{ng} \cdot \mathrm{mL}^{-1}$.

\section{Statistical analysis}

MUC5AC mRNA, TLR2 mRNA and MUC5AC protein after exposure to M. pneumoniae at 10, 20 and $50 \mathrm{cfu} \cdot \mathrm{cell}^{-1}$ were first compared within groups as compared with the respective negative, unexposed control. This was followed by comparison of fold changes between asthma and normal groups from their respective negative, unexposed controls to compare group differences (asthma and normal control), time differences and mediator concentration differences employing a mixed effects model (repeated measures analysis). If the overall $\mathrm{p}$-value for the model was significant, individual comparisons were performed to determine which individual concentrations, time-points and group differences achieved significance. Data are expressed as means \pm SEM and a p-value of $<0.05$ was considered statistically significant.

\section{RESULTS}

\section{Subject characteristics}

The characteristics of the subjects included in the study are shown in table 1.

\section{MUC5AC mRNA and protein expression}

Baseline MUC5AC mRNA expression, as expressed by $\mathrm{Ct}$ and adjusted for baseline glyceraldehyde phosphate dehydrogenase (GAPDH) expression, was not different between the asthma and control epithelial cells prior to $M$. pneumoniae exposure ( $\Delta \mathrm{Ct}$ (MUC5AC Ct-GAPDH Ct) $10.57 \pm 1.50$ versus $8.87 \pm 1.13$ in the asthma and control groups, respectively; $\mathrm{p}=0.50$ ). MUC5AC protein at baseline was significantly higher in the asthmatic cells compared with normal controls (optical density in asthma versus control cells $0.14 \pm 0.04$ versus $0.04 \pm 0.009 ; \mathrm{p}=0.03$ ). Protein results are expressed as a ratio of unexposed cells to control for these baseline differences. Total protein was higher in the asthmatic group but the difference did not achieve statistical significance $(130 \pm 19$ versus $80 \pm 23 \mathrm{pg} \cdot \mathrm{mL}^{-1}$ in asthma versus control subjects; $\mathrm{p}=0.12$ ).

Fold changes in MUC5AC mRNA and protein expression after exposure to M. pneumoniae for $48 \mathrm{~h}$ in the asthmatic and normal control cells are shown in figure 1. Addition of the NF$\kappa \mathrm{B}$ inhibitor, TLR2 inhibitor (data for $50 \mathrm{cfu} \cdot \mathrm{cell}^{-1}$ condition only) or use of the mutant $M$. pneumoniae organism significantly attenuated the effects of M. pneumoniae on MUC5AC expression in both asthmatic and normal airway epithelial cells (fig. 2).

\begin{tabular}{|c|c|c|c|}
\hline & Asthma & Normal & $\mathrm{p}$-value \\
\hline Subjects $n$ & 11 & 6 & \\
\hline Sex M/F & $4 / 6$ & $3 / 3$ & \\
\hline Age yrs & $33 \pm 7$ & $26 \pm 4$ & 0.44 \\
\hline Medication & Albuterol ${ }^{\#}$ & None & \\
\hline FEV 1 L & $2.8 \pm 0.3$ & $3.8 \pm 0.4$ & 0.05 \\
\hline FEV $1 \%$ pred & $83 \pm 5$ & $99 \pm 4$ & 0.02 \\
\hline $\mathrm{FEV}_{1} / \mathrm{FVC}$ & $66 \pm 7$ & $81 \pm 4$ & 0.11 \\
\hline Methacholine $\mathrm{PC}_{20} \mathrm{mg} \cdot \mathrm{mL}^{-1}$ & $0.59 \pm 0.2$ & $>25$ & 0.01 \\
\hline \multicolumn{4}{|c|}{ 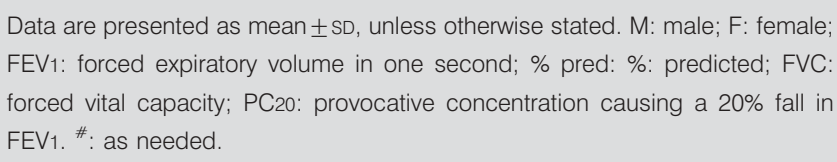 } \\
\hline
\end{tabular}



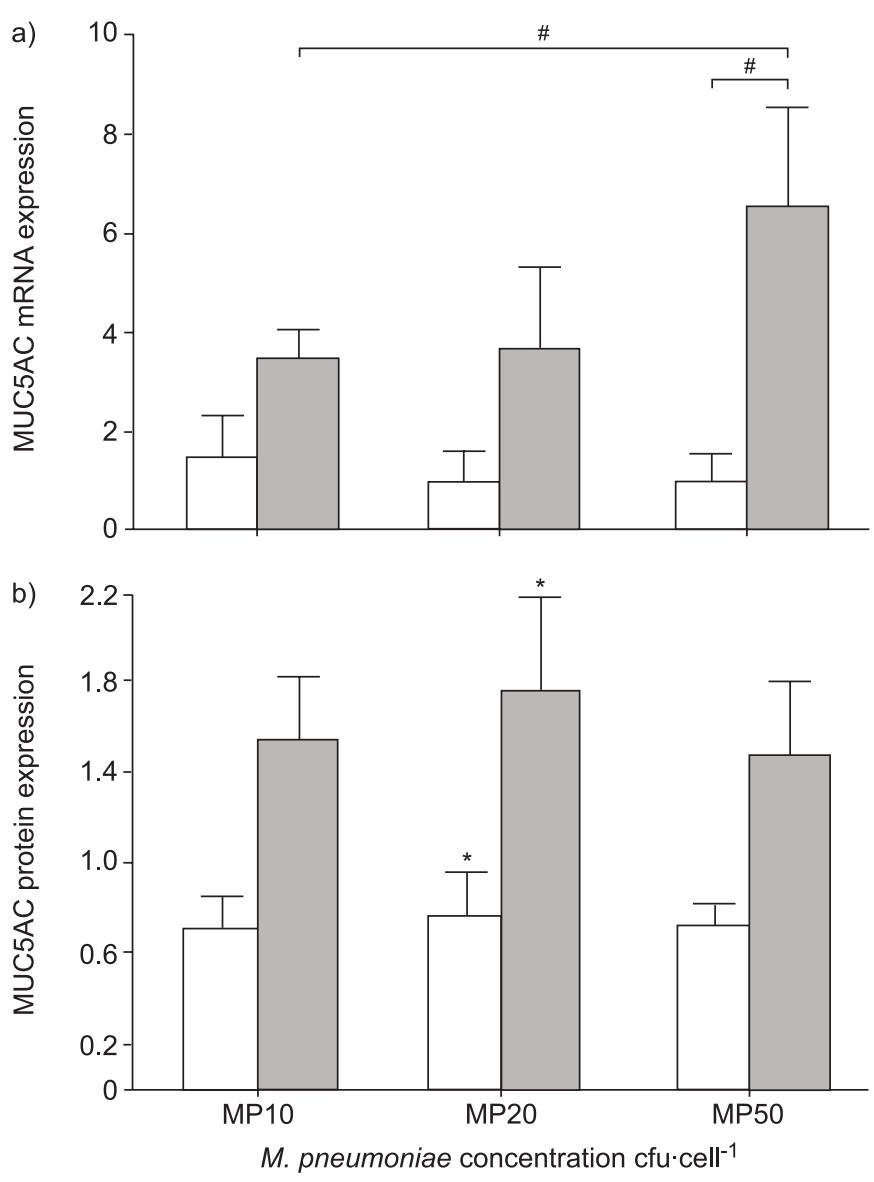

FIGURE 1. Fold changes in a) MUC5AC mRNA expression and b) MUC5AC protein after exposure to Mycoplasma pneumoniae for $48 \mathrm{~h}$ at 10 (MP10), 20 (MP20) and 50 (MP50) colony forming units (cfu) $\cdot$ cell $^{-1}$ in airway epithelial cells isolated from asthmatic subjects $(\square ; n=11)$ and normal control subjects $(\square ; n=6)$. *: $p<0.05$; ${ }^{*}: p<0.05$ between each respective pair.

\section{TLR2 mRNA expression}

Baseline TLR2 mRNA expression was not different between asthma and control epithelial cells prior to $M$. pneumoniae exposure $(\Delta \mathrm{Ct}$ (TLR2 $\mathrm{Ct}-\mathrm{GAPDH} \mathrm{Ct}) \quad 6.63 \pm 0.89$ versus $5.2 \pm 0.35$ in the asthma and control groups, respectively; $\mathrm{p}=0.40$ ). Fold changes in TLR2 expression in asthmatic and normal airway epithelial cells after exposure to $M$. pneumoniae are shown in figure 3.

\section{DISCUSSION}

Results of the present investigation demonstrate, for the first time in humans, that gene and protein expression of the major mucin protein in human airways, MUC5AC, is increased in airway epithelial cells isolated directly from asthmatic subjects after exposure to the pathogen M. pneumoniae, as compared with airway epithelial cells isolated directly from normal control subjects. This effect was abrogated when a TLR2 inhibitor and an NF- $\mathrm{kB}$ inhibitor were added, respectively. TLR2 mRNA was also increased in asthmatic airway epithelial cells but not in normal airway epithelial cells $4 \mathrm{~h}$ after exposure. These data suggest that $M$. pneumoniae induces MUC5AC expression preferentially in asthma, as compared

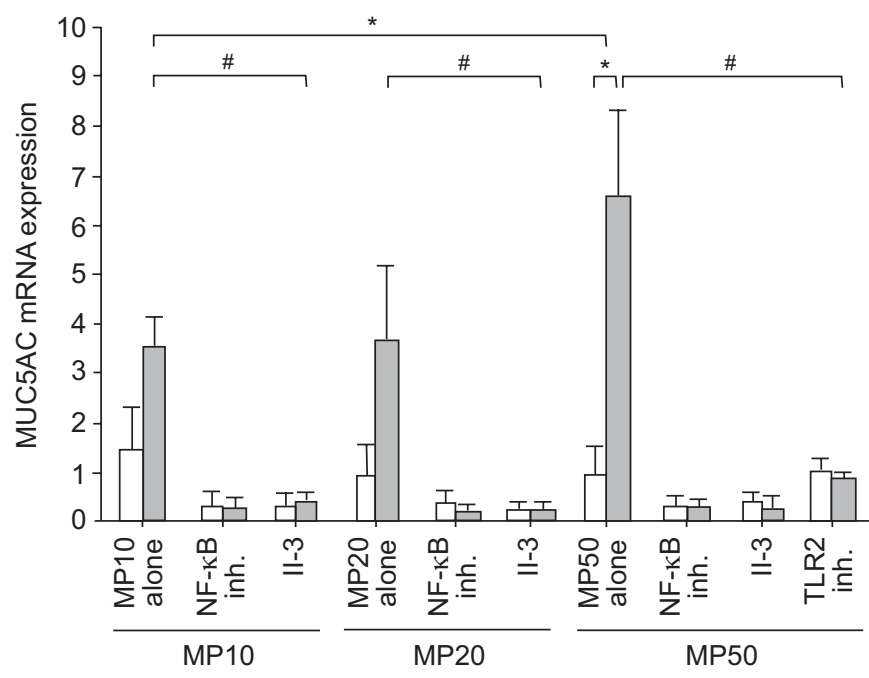

FIGURE 2. Fold changes in MUC5AC mRNA expression in airway epithelial cells from asthmatic $(\square ; n=11)$ and normal control $(\square ; n=6)$ subjects after exposure to Mycoplasma pneumoniae for $48 \mathrm{~h}$ at 10 (MP10), 20 (MP20) and 50 (MP50) colony forming units.per cell ${ }^{-1}$, cafeic acid phenylethyl ester, a nuclear factor-kB inhibitor (NF-kB inh.), M. pneumoniae organism strain II-3 (II-3), which contains a mutation at the $\mathrm{P} 1$ adhesin and cannot bind airway epithelial cells, and a toll-like receptor 2 inhibitor (TLR2 inh.). *: $p<0.05$ between each respective pair; *: $p<0.05$ between $M$. pneumoniae alone versus $M$. pneumoniae plus each of the inhibitors (NF-KB inh., II-3 and TLR2 inh.).

with airway epithelial cells from normal subjects. The persistence of phenotypic group differences ex vivo in isolated airway epithelial cells suggests that asthmatics may have an inherently augmented epithelial response to infectious challenges, independent of adaptive immune mechanisms.

Several infectious agents have been shown to increase mucin gene expression, including rhinovirus, respiratory syncytial

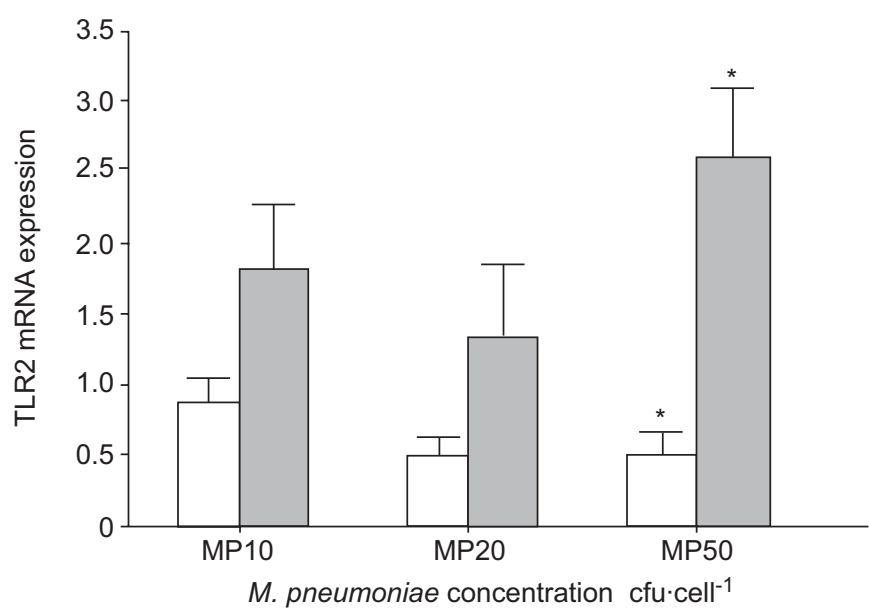

FIGURE 3. Fold changes in toll-like receptor (TLR)2 mRNA expression after exposure to Mycoplasma pneumoniae for $4 \mathrm{~h}$ at 10 (MP10), 20 (MP20) and 50 (MP50) colony forming units (cfu) $\cdot \mathrm{cell}^{-1}$ in airway epithelial cells isolated from asthmatic subjects ( $\square ; n=11$ ) and normal control subjects $(\square ; n=6)$. *: $p<0.05$. 
virus and $H$. influenzae. $[2,3,5,17]$. The present investigation is unique in that airway epithelial cells were isolated from wellcharacterised patients with asthma and normal controls, cultured at an air-liquid interface and exposed to $M$. pneumoniae in a dose-response manner. It is notable that the fold change in MUC5AC mRNA was higher than the fold change in MUC5AC protein. Secreted and not total MUC5AC protein was focused on; the former is potentially more relevant during an acute infection. In future studies, the present authors intend to evaluate the secreted and stored MUC5AC. The concentrations of $M$. pneumoniae used in the present study's experiments were lower than those reported in acute infection resulting in pneumonia, where concentrations are generally 100-200 cfu $\cdot$ cell $^{-1}$ (G. Cassell, University of Alabama, Birmingham, AL, USA; personal communication). The concentrations were therefore chosen for study to more closely mimic a subacute infection that could potentially exacerbate asthma.

The mechanism of this differential response in mucin expression to M. pneumoniae in asthma appears to involve the TLR2 receptor and NF- $\kappa \mathrm{B}$ activation; the lack of MUC5AC expression after exposure to both a TLR2 inhibitor and an NF-kB inhibitor supports this assumption. Additional studies are needed that utilise more time-points and concentrations of $M$. pneumoniae, with a TLR2 agonist and antagonist to determine whether TLR2 is the main pathway employed by $M$. pneumoniae. The present study's results support those of CHU et al. [4] in BALB/c mice infected with M. pneumoniae, where maximum TLR2 activation occurred at $4 \mathrm{~h}$ and maximum MUC5AC expression occurred at 48-72 h.

In summary, the present study has shown that Mycoplasma pneumoniae significantly enhances MUC5AC gene and protein expression in airway epithelial cells isolated directly from subjects with asthma. In contrast, minimal effect is seen with Mycoplasma pneumoniae exposure in airway epithelial cells isolated from normal subjects. Maintenance of the phenotype ex vivo suggests that asthmatic epithelial cells may be primed to respond vigorously to infectious agents.

\section{REFERENCES}

1 Fahy JV. Goblet cell and mucin gene abnormalities in asthma. Chest 2002; 122: Suppl. 6, 320S-326S.

2 Adler KB, Li Y. Airway epithelium and mucus: intracellular signaling pathways for gene expression and secretion. Am J Respir Cell Mol Biol 2001; 25: 397-400.

3 Sethi S. Coinfection in exacerbations of COPD: a new frontier. Chest 2006; 129: 223-224.
4 Chu HW, Jeyaseelan S, Rino JG, et al. TLR2 signaling is critical for Mycoplasma pneumoniae-induced airway mucin expression. J Immunol 2005; 174: 5713-5719.

5 Hashimoto K, Graham BS, Ho SB, et al. Respiratory syncytial virus in allergic lung inflammation increases Muc5ac and gob-5. Am J Respir Crit Care Med 2004; 170: 306-312.

6 Inoue D, Yamaya M, Kubo H, et al. Mechanisms of mucin production by rhinovirus infection in cultured human airway epithelial cells. Respir Physiol Neurobiol 2006; 154: 484-499.

7 Esposito S, Blasi F, Arosio C, et al. Importance of acute Mycoplasma pneumoniae and Chlamydia pneumoniae infections in children with wheezing. Eur Respir J 2000; 16: 1142-1146.

8 Esposito S, Droghetti R, Bosis S, Claut L, Marchisio P, Principi N. Cytokine secretion in children with acute Mycoplasma pneumoniae infection and wheeze. Pediatr Pulmonol 2002; 34: 122-127.

9 Lieberman D, Lieberman D, Printz S, et al. Atypical pathogen infection in adults with acute exacerbation of bronchial asthma. Am J Respir Crit Care Med 2003; 167: 406-410.

10 American Thoracic Society Board of Directors. Standards for the diagnosis and care of patients with chronic obstructive pulmonary disease (COPD) and asthma. Am Rev Respir Dis 1987; 136: 225-244.

11 Kraft M, Striz I, Georges G, et al. Expression of epithelial markers in nocturnal asthma. J Allergy Clin Immunol 1998; 102: 376-381.

12 Chu HW, Balzar S, Seedorf GJ, et al. Transforming growth factor- $\beta 2$ induces bronchial epithelial mucin expression in asthma. Am J Pathol 2004; 165: 1097-1106.

13 Abdel-Latif MM, Windle HJ, Homasany BS, Sabra K, Kelleher D. Caffeic acid phenethyl ester modulates Helicobacter pylori-induced nuclear factor- $\kappa \mathrm{B}$ and activator protein-1 expression in gastric epithelial cells. $\mathrm{Br} J$ Pharmacol 2005; 146: 1139-1147.

14 Krause DC, Leith DK, Wilson RM, Baseman JB. Identification of Mycoplasma pneumoniae proteins associated with hemadsorption and virulence. Infect Immun 1982; 35: 809-817.

15 Wenzel SE, Trudeau JB, Barnes S, et al. TGF- $\beta$ and IL-13 synergistically increase eotaxin-1 production in human airway fibroblasts. J Immunol 2002; 169: 4613-4619.

16 Park JA, He F, Martin LD, Li Y, Chorley BN, Adler KB. Human neutrophil elastase induces hypersecretion of mucin from well-differentiated human bronchial epithelial cells in vitro via a protein kinase $C \Delta$-mediated mechanism. Am J Pathol 2005; 167: 651-661.

17 Peebles RS Jr, Graham BS. Viruses, dendritic cells and the lung. Respir Res 2001; 2: 245-249. 